\title{
Water Use and Conservation in Manufacturing: Evidence from U.S. Microdata
}

by

\author{
Randy A. Becker \\ Center for Economic Studies \\ U.S. Census Bureau
}

CES 15-16

June, 2015

The research program of the Center for Economic Studies (CES) produces a wide range of economic analyses to improve the statistical programs of the U.S. Census Bureau. Many of these analyses take the form of CES research papers. The papers have not undergone the review accorded Census Bureau publications and no endorsement should be inferred. Any opinions and conclusions expressed herein are those of the author(s) and do not necessarily represent the views of the U.S. Census Bureau. All results have been reviewed to ensure that no confidential information is disclosed. Republication in whole or part must be cleared with the authors.

To obtain information about the series, see www.census.gov/ces or contact Fariha Kamal, Editor, Discussion Papers, U.S. Census Bureau, Center for Economic Studies 2K132B, 4600 Silver Hill Road, Washington, DC 20233, CES.Papers.List@census.gov. 


\begin{abstract}
Water can be a scarce resource, particularly in certain places at certain times. Understanding both water use and conservation efforts can help ensure that limited supplies can meet the demands of a growing population and economy. This paper examines water use and recirculation in the U.S. manufacturing sector, using newly recovered microdata from the (defunct) Survey of Water Use in Manufacturing, merged with establishment-level data from the Annual Survey of Manufactures and the Census of Manufactures. Results suggest that water use per unit of output is largest for larger establishments, in part because larger establishments use water for more purposes. Larger establishments are also found to recirculate water more - satisfying water use needs without necessarily increasing water intake. Various costs also appear to play a role in water recirculation. In particular, the water circulation rate is found to be higher when water is purchased from a utility. Relatively low (internal) prices for self-supplied water could suppress the incentive to invest in recirculation. Meanwhile, establishments with higher per-gallon water intake treatment costs also recirculate more, as might be expected. The cost associated with water discharge - due to regulation or otherwise - also increases circulation rates. The aridity of a locale is found to have little effect on circulation rates.
\end{abstract}

Keyword: water use, water recirculation, U.S. manufacturing

JEL Classification: Q25, L6

\footnotetext{
* This paper has benefited from helpful feedback on earlier versions, including comments from Lucia Foster, Joseph Shapiro, and session participants at the Association of Environmental and Resource Economists (AERE), International Water Resource Economics Consortium (IWREC), and Comparative Analysis of Enterprise Data (CAED) conferences. Any opinions and conclusions expressed herein are those of the author and do not necessarily reflect the views of the U.S. Census Bureau. All results have been reviewed to ensure that no confidential information is disclosed. If interested, contact the author (randy.a.becker@census.gov) for the latest version of this paper.
} 


\section{Introduction}

Water can be a scarce resource, particularly in certain places at certain times. In the United States, a substantial share of the population - upwards of $66 \%$ - lives in areas vulnerable to water shortages (Padowski and Jawitz 2012). Understanding both water use and conservation efforts can help ensure that limited supplies can meet the demands of a growing population and economy. This paper examines water use and recirculation in the U.S. manufacturing sector, using newly recovered microdata from the (defunct) Survey of Water Use in Manufacturing, merged with establishment-level data from the Annual Survey of Manufactures and the Census of Manufactures.

In the United States, the quantity of water used in manufacturing pales in comparison to the share of total water intake for thermoelectric power (49\%) and for irrigation (31\%), and is roughly on par with total domestic/residential water use (Kenny et al. 2009). But unlike some other water uses, recirculation is a distinct possibility in industrial settings, reducing the need for new water intake. Reducing industrial water intake by just $1 \%$ (through increased recirculation or otherwise) would leave untouched approximately 222 million gallons of water per day - enough water to serve 2.3 million people. ${ }^{1}$ This amount would serve the domestic needs of the entire San Antonio or Las Vegas metropolitan areas, or over $70 \%$ of the San Diego metro area, to say nothing of alternate uses.

Despite this, industrial water use has received relatively little attention in the economics

\footnotetext{
${ }^{1}$ According to the U.S. Geological Survey (Kenny et al. 2009), in 2005, 258 million people were served publicly with 25,600 million gallons per day for "domestic use" and an additional 43 million people were self-supplied with 3,830 million gallons per day. This implies a usage of 97.8 gallons per day per person. Meanwhile, manufacturing industries self-supplied 18,200 million gallons per day in 2005 . In 1995, about $82 \%$ of industrial water was selfsupplied (Solley et al. 1998), the last year this estimate was made. Assuming this same proportion, total manufacturing water intake in 2005 was approximately 22,195 million gallons per day.
} 
literature, relative to agricultural, residential, and recreational uses. Among the notable exceptions are studies that have used Canada's Industrial Water Use Survey. Similar studies on U.S. manufacturing have not been conducted because of the lack of comprehensive survey data. The current paper attempts to fill this void, exploring water use and recirculation at U.S. manufacturing plants, using heretofore unavailable microdata from the U.S. Census Bureau's Survey of Water Use in Manufacturing (SWUM) from 1973 and 1978. These data were among the many historic data files recovered from tape by the Census Bureau's Center for Economic Studies in 2009-2010.

Results suggest that water use per unit of output is largest for larger establishments, in part because larger establishments use water for more purposes. Larger establishments are also found to recirculate water more - satisfying water use needs without necessarily increasing water intake. Various costs also appear to play a role in water recirculation. In particular, the water circulation rate is found to be higher when water is purchased from a utility. Relatively low (internal) prices for self-supplied water could suppress the incentive to invest in recirculation. Meanwhile, establishments with higher per-gallon water intake treatment costs also recirculate more, as might be expected. The cost associated with water discharge - due to regulation or otherwise - also increases circulation rates. The aridity of a locale is found to have little effect on circulation rates.

This paper proceeds as follows. Section 2 discusses some of the previous literature in this area. Section 3 provides an overview of water use in U.S. manufacturing, while section 4 describes the SWUM and the recovered microdata. Section 5 presents results, while section 6 concludes. 


\section{Previous Literature}

Industrial water use has received relatively little attention in the economics literature, relative to agricultural, residential, and recreational uses. Among the notable exceptions is a series of papers by Steven Renzetti and coauthors that use Canada's Industrial Water Use Survey (IWUS). In the first of these, Renzetti (1992) estimates (negative) own-price elasticity for water intake for several manufacturing sectors. He also finds water recirculation to be substitutes for both water intake and water discharge. Renzetti (1993) examines manufacturers' choice to use publicly-supplied water (versus self-supplied water) and finds that larger firms are more likely to self-supply water, as are those that face lower water purification costs and higher annual public utility connection fees. He also finds that, in general, publiclysupplied firms' water intake is more sensitive to external prices but less sensitive to the level of production.

Dupont and Renzetti (1998) look at water use, treatment, recirculation, and discharge in Canadian food processing industries in particular. In a later paper, Dupont and Renzetti (2001) estimate translog cost functions to examine the relationship between water and non-water inputs. They find that water intake is a substitute for water recirculation, labor, energy, and capital, while water recirculation is a substitute for labor and complement to energy and capital.

Bruneau and Renzetti (2010) examine water use in Canada's business sectors (including non-manufacturing) between 1981 and 1996. They find that, while water use has increased over all, water intake intensities have actually declined and gross water use intensities even 
more so - partly because of technique and partly because of decreases in the relative size of some water intensive industries. Meanwhile, recycling intensities have decreased and consumption intensities have increased in nonagricultural sectors.

Bruneau, Renzetti, and Villeneuve (2010) examine the factors behind manufacturers' decision to recirculate water and how much to recirculate. Recirculation is found to be more prevalent in larger plants, when intake water must be treated prior to use, in certain heavy water-using industries, and in drier regions. Meanwhile, the quantity of water recirculated depends positively on the size of the plant, the price of intake water, and the price of water treatment prior to discharge. In more recent work, these authors explore these issues further, using longitudinal data on the decision to recirculate or not (Bruneau and Renzetti 2014).

Together, these studies shed light on manufacturers' demand for water, self-supplied

water, recirculated water, and the role water plays in manufacturing. Most of these studies use the microdata (versus the aggregate data) from the Canadian IWUS of 1986, 1991, and/or 1996, which share similarities to the U.S. microdata used in this paper. However, the absence of a number of key expenditure items - such as those that permit the construction of (internal) prices of various types of water - prevent similar analyses.

\section{Overview of Water Use in U.S. Manufacturing}

In 2005 , the U.S. manufacturing sector self-supplied 18.2 billion gallons of water per day, accounting for about $4.4 \%$ of total water withdrawals in the United States (Kenny et al. 2009). Additional water is supplied to the manufacturing sector by public and private water 
suppliers. ${ }^{2}$ Water is used in a number of ways in manufacturing facilities. It can be used to clean, cool, and/or convey intermediate inputs; it can be embedded in the final product itself (e.g., beverages); it can be used in generating steam for electric power generation; and it can be used for "domestic" purposes, such as drinking and sanitation. Table 1 shows the percent of water intake and the percent of gross water use, by purpose, for U.S. manufacturing in 1973 and 1978 (U.S. Census Bureau 1976, 1981). Water for other cooling \& condensing, for process, and for steam electric power generation dominate here, in that order. ${ }^{3}$

Table 2 shows the top ten water-using manufacturing industries (4-digit SIC) in 1978, in terms of gallons of water intake, intensity of water intake (i.e., gallons per dollar of value added, in 1978 dollars), gallons of gross water use, and intensity of gross water use, respectively. Twenty different industries appear here, dominated by those in chemicals, primary metals, paper, and petroleum refining sectors. Water use is relatively concentrated, with the top ten industries (in terms of gallons of water intake) accounting for $68 \%$ of the manufacturing sector's total water intake. We also see just how critical water is to these industries - with hundreds of gallons needed for just one dollar of output. In the most extreme cases, 1,180 gallons of water is used per $\$ 1$ of value added at paper mills (SIC 2621), and 446 gallons of water is taken in per $\$ 1$ of value added at building paper and board mills (SIC 2661).

\footnotetext{
${ }^{2}$ Data on the delivery of water by such suppliers was last published for 1995 (see Solley et al. 1998). In that year, the U.S. manufacturing sector self-supplied 22.4 billion gallons of water per day, or about $5.6 \%$ of total water withdrawals in the United States. Another 4.8 billion gallons, or $1.2 \%$, came from public and private water suppliers. In 1973 and 1978 - the years studied in this paper - manufacturers self-supplied $89 \%$ and $82 \%$ of their water, respectively.

${ }^{3}$ Water used for hydroelectric power generation is not withdrawn and is not included here.

${ }^{4}$ Even in today's dollars, this represents hundreds of gallons of water per dollar of output.
} 
Interestingly, as seen in Figure 1, aggregate water use by U.S. manufacturing rose from

1954 to a peak in 1978 before declining in 1983, while aggregate water intake by U.S.

manufacturing actually peaked a decade earlier, in 1968, before declining (U.S. Bureau of the

Census 1986). ${ }^{5}$ The difference between the two is water recirculated and reused. ${ }^{6}$ As seen in

Figure 2, in 1954, each gallon taken in by the manufacturing sector was used 1.82 times. This

circulation rate peaked in 1978 at 3.42, before declining slightly to 3.37 in 1983 (the last year

the Census Bureau collected the SWUM). This increase in the circulation rate occurred at a

time when the percent of manufacturers recirculating water was more or less declining (see

\footnotetext{
${ }^{5}$ This publication contains the following caution regarding the 1983 water use and reuse statistics: "During the review of the 1983 data, it was apparent that respondents interpreted the instructions for reporting recirculated and reused water in a variety of ways. This was due to the general nature of the instructions coupled with differing technologies and systems for recirculating water. The result was inconsistencies in the data received. Many of the major water users were contacted and data corrections obtained. However, we were unable to contact all establishments to confirm the consistency of the data. Thus, figures on recirculated and reused water (and to a lesser extent, gross water used) are of lower reliability than the water intake and water discharged statistics presented in this report." It is not clear whether these same concerns should perhaps apply to data from other years as well. No similar concern was raised in those publications. As will be discussed in the next section, the questions on gross water used and water recirculated/reused took different forms between 1983, 1978, and 1973. ${ }^{6}$ There is puzzling ambiguity on this point. The footnote to Table 1c in U.S Bureau of the Census (1986) states: "Total gross water used is equal to sum of water intake plus water recirculated and reused without regard to evaporation." However, in this table of historical statistics, this identity only holds for 1983 . For 1978, the values suggest 44,494 (billion gallons) $=12,992+34,199$, which obviously is not true. When these 1978 statistics were first published (in U.S. Bureau of the Census 1981), there is no clear explanation for this inequality. Table 1a in the 1981 publication suggests that "total gross water used is equal to the sum of water intake and water recirculated and reused less evaporation and consumption", which is a slightly different definition, but one that also doesn't explain the inequality. That definition is also contradicted by the definition suggested in a footnote to Table $1 b$ in the same publication: "Suppressed values for gross water used may be estimated from data shown for water intake and recirculated water." Meanwhile, for 1973, the quantity of water recirculated is suppressed in Table 1c of U.S. Bureau of the Census (1986). A footnote explains: "For 1973, data for recirculated and reused water were not collected but were derived from gross water used and water intake. Derived recirculated and reused water data are not directly comparable to 1978 and 1983 and, therefore, are not presented." Why there would be incomparability is unclear. When the 1973 statistics were first published (in U.S. Bureau of the Census 1976), water recirculated was clearly derived by the same identity: "gross water used minus water intake." Finally, for 1954-1968, in the 1986 table of historical statistics, the water recirculated and reused column contains "(NA)", or not available, without any further explanation. Again, it is not clear why the identity was not simply applied, since the definitions of gross water use, recirculation, and intake appear the same here as in later years. Here and throughout, I will assume the strict identity: gross water used is the sum of water intake plus water recirculated/reused.
} 
also Figure 2). This suggests a sharp increase in the intensity of recirculation among those that did recirculate.

This paper will seek to understand the determinants of water use and water

recirculation of U.S. manufacturers during this very interesting period of 1973 and 1978 - the period when gross water use was increasing, but water intake was actually falling, and water recirculation increased dramatically. ${ }^{7}$

\section{The Survey of Water Use in Manufacturing}

Since the Survey of Water Use in Manufacturing (SWUM) is now relatively unknown, a fairly detailed description seems warranted. The SWUM was conducted on seven occasions from 1954 to 1983 , when it was discontinued for budgetary reasons. ${ }^{8}$ During this time, establishments were asked to report very basic information about their water use in the

\footnotetext{
${ }^{7}$ This paper will not separately consider water consumed in process - either embedded in the final product or through evaporation. This can be derived by subtracting water discharged from water intake. According to U.S. Census Bureau (1986), between 6 to 11 percent of the water intake [2.0\% and 3.7\% of gross water used] by the manufacturing sector was consumed, depending on the year. That $90 \%$ or more of water intake is eventually discharged by manufacturers (usually into rivers, streams, and other surface waters, less typically into public utility sewers or to the ground) may suggest that consumption is of more relevance than water intake or gross water use, especially if water availability is of particular concern. However, water quality is also important, in which case the quantity of water intake, its function within the manufacturing plant, and its treatment before discharge are all important too. Unfortunately, the SWUM does not have ideal measures of the quality of discharged water. We do know that untreated water accounted for $87 \%, 77 \%, 71 \%, 70 \%, 56 \%, 60 \%$, and $55 \%$ of discharged water in 1954 , $1959,1964,1968,1973,1978$, and 1983, respectively (U.S. Bureau of the Census 1986). However, "untreated" does not necessarily imply degradation in quality. Likewise, "treated" does not imply the opposite. In any event, reductions in water intake seem unambiguously good by leaving more water untouched. And one would expect reductions in water intake to come mostly from greater recirculation than from reductions in consumption. The study of residential water use also tends to focus on intake and use rather than consumption. Here, too, most water is discharged.

${ }^{8}$ U.S. Bureau of the Census (1992) notes that one of the seven planned reports in the 1987 Census of Manufactures Subject Series was eliminated, specifically: "Water Use in Manufacturing. Because of a lack of funding, this report was eliminated."
} 
quinquennial Census of Manufactures (CM), including a range of gallons of water intake. ${ }^{9}$

Those reporting more than 20 million gallons of water intake in the CM received the SWUM the following year, asking more detailed information. ${ }^{10}$ (Though the reference year for the SWUM data is the year after the $\mathrm{CM}$, these data were published as part of the CM Subject Series.) According to the publications, upwards of $97 \%$ of the water withdrawn by the manufacturing sector is by the $3-4 \%$ of plants that took in more than 20 million gallons. During the 1970 , these relatively few plants accounted for $34-43 \%$ of U.S. manufacturing employment and 47 $54 \%$ of the value added in the U.S. manufacturing sector.

The information collected on the SWUM varied somewhat over time, in both detail and in scope. Here, I will focus mainly on the content of the 1973 and 1978 surveys - the focus of this paper. The 1973 survey form and instructions only appear to be available at the National Archives in Washington DC. Photographic images are available from the author. Meanwhile, the 1978 SWUM form can be found in U.S. Bureau of the Census (1981) and is reproduced in the appendix for reference purposes.

Respondents to the SWUM were asked to report their water intake (in millions of gallons) from five sources (public water system, whether municipally or privately owned; owncompany surface water system, such as streams or lakes; own-company ground water system,

\footnotetext{
${ }^{9}$ Depending on the CM, respondents selected from one of six ranges (1987, 1982, 1977), three ranges (1972), five ranges $(1967,1963)$, or four ranges (1954). In only 1972, respondents were asked about their water use, which was explicitly to "include water recirculated and reused." In all other CMs, the primary question was on range of water intake (not use). The CMs of 1977, 1982, and 1987, further asked respondents whether or not they recirculated any water. In the 1954 and $1963 \mathrm{CMs}$, respondents were asked about their principal source of water (utility versus other/self-supplied). The $1954 \mathrm{CM}$ also asked about the kind of water (fresh, brackish, or both). The $1958 \mathrm{CM}$ did not include water questions at all (see explanation below). Meanwhile, water use questions were on the 1987 CM, but a 1988 SWUM was never conducted. The 1992 CM was the first CM without water questions since 1947.

${ }^{10}$ The exception to this sample selection was the 1959 survey. The $1958 \mathrm{CM}$ did not include any water-related questions. Instead, the sample for the 1959 survey included all establishments reporting substantial water use in the 1954 survey, plus establishments in certain water-intensive industry groups that had at least 100 employees.
} 
such as wells or deep springs; own-company tide water system from estuaries, bays, or oceans; other sources) by three types (fresh; brackish; salt). Here, brackish water is water with 1,000 to 10,000 parts per million of dissolved solids, while salt water is water with more than 10,000 parts per million of dissolved solids. In 1973, respondents were asked about the treatment of intake water, by nine different methods of treatment (physical treatment: settling, screening, equalization; coagulation; softening; ion exchange; neutralization ( $\mathrm{pH}$ control); aeration; filtration; chlorination; other). Questions about the treatment of intake water prior to use did not appear in the 1978 survey.

Respondents were also asked to report their water intake for seven purposes (process; steam electric power generation; air conditioning; other cooling \& condensing; sanitary services; boiler feed; other uses) and again by three types (fresh; brackish; salt). Here, "process water is all water that comes directly in contact with products and/or materials, including water which is consumed in the manufacturing of products." Meanwhile, water for "other cooling and condensing" is used "in conjunction with the operation of process equipment, but which does not come in direct contact with products or materials." Sanitary service includes water used for drinking, cafeterias, and domestic sewage.

In addition to water intake, respondents were also asked to report the gallons of gross water used by the seven purposes (listed above). Gross water used is the water intake for a particular purpose plus the water recirculated for that purpose. To clarify, these instructions were provided to respondents: "[Gross water used is] the estimated quantity of water that would have been required if no water had been recirculated or reused. For example: If total water intake (Item 1) was 400 million gallons and of this 400 million gallons, 100 million gallons 
were used twice for cooling purposes and once for washing products or materials, the total water required would be 300 million gallons (less consumption and evaporation loss), plus the 300 million gallons not recirculated, for a total of 600 million gallons." On the 1978 form, respondents were explicitly asked for all three measures - water intake, water recirculated/reused, and gross water used - while on the 1973 form, water recirculated/reused is implicit. ${ }^{11}$ As with water intake, the 1973 survey further inquired about the treatment of recirculated water, by nine different methods of treatment (listed above), while the 1978 survey had no questions about the treatment of recirculated water.

The SWUM also collected data on water discharged (in millions of gallons) into seven different points (public utility sewer; streams \& rivers; lakes \& ponds; bays \& estuaries; ocean; ground (wells, spray, seepage, etc.); transferred to other users) and by whether the water was treated or not. Respondents were also asked to report their water discharge by the water's final purpose (i.e., the seven purposes listed above) and by whether the water was treated or not. Respondents were further asked to report their water discharge by eleven types of treatment (untreated; surface skimming (e.g., oil separation); neutralization (pH control); coagulation; flotation; primary settling; biological oxidation (tricking filters, activated sludge, digestion basins, ponds, and lagoons); secondary settling; filtration; chlorination; other). In 1978, respondents were to provide detail by treatment type and final purpose.

The 1973 and 1978 surveys also collected information on water-related expenditures the only two years of the survey to do so. The questions, however, took very different forms in

\footnotetext{
${ }^{11}$ Meanwhile, on the 1983 survey form, water intake and water recirculated/reused was asked and gross water used is implicit. In the previous section, I noted a caution that appeared in the publication regarding the 1983 water use and reuse statistics. Perhaps the different form of this question (where gross water use was not explicitly asked) led to confusion.
} 
these two years. On the 1973 survey, respondents were asked to report both their "total expenditures in 1973 for new water treatment plant and equipment that were capitalized in fixed asset accounts" and "total annual costs [material, parts, fuel, power, labor, depreciation, leasing, contracted services] incurred in 1973 to operate and maintain your existing water treatment plant and equipment." These respondents were further asked to estimate the percentages of these two amounts that were attributable to the "treatment of intake water prior to use." Respondents in 1973 were also asked to report the share of operating costs attributable to depreciation and to equipment leasing.

On the 1978 survey, respondents were asked to report both their "capital expenditures for abatement of water pollutants" and "annual operating costs for abatement of water pollutants."12 Though the questions are worded somewhat differently, the 1978 and 1973 expenditures data are compared to each other in tables, suggesting that they were meant to be measure the same concepts across these years. Unlike the 1973 survey, respondents to the 1978 survey were not asked about the share of these expenditures specifically attributable to the treatment of intake water prior to use. Similar to 1973, however, respondents were asked to report the share of operating costs attributable to depreciation and to equipment leasing, but also labor, private contractor services, and materials and supplies (including fuel and power).

The 1978 survey asked respondents for some additional expenditure items that the 1973 survey did not. One item was estimated gross value of assets (original cost) of in-place plant and equipment for abatement of water pollutants. Other items relate to the use of land

\footnotetext{
${ }^{12}$ Instructions indicate that these two items were to be equivalent to Item $3 c$ and Item $7 a-c$, respectively, on the Pollution Abatement Costs and Expenditures (PACE) survey, for respondents that were in both surveys.
} 
in the abatement of water pollutants (for settling points, drying beds, equalization basins, sludge lagoons, etc.). These items included an estimate of the number of acres of land used in the abatement of water pollutants, the share of such land that is rented and/or leased, and an estimate of the rental cost of such land.

In addition to the differences already mentioned, the 1973 also collected data on six water quality measures (biochemical oxygen demand, oil and grease, suspended solids, total metals, nutrients, and average temperature) at three stages: intake (before treatment), discharge (before treatment), and discharge (after treatment). Tabulations of these data were not published, perhaps because of data quality concerns. ${ }^{13}$

\subsection{The Recovery and Development of SWUM Microdata}

The 1973 and 1978 SWUM microdata were among the many historic files recovered from tape by the Census Bureau's Center for Economic Studies in 2009-2010 using an old, faltering Unisys Clearpath IX 4400 mainframe - the last of its kind and a descendant of the earliest mainframes ever in existence. ${ }^{14}$ There were numerous and unique challenges in creating research-ready datasets from data written to computer tape decades ago. First, the data were stored in an arcane, proprietary file format (CENIO). Files could not simply be copied to another computer system. Further, the data within a file were completely unstructured, requiring a paper record layout to make sense of each bit of data. In the case of the 1973 SWUM data, half the record layout is missing from the paper file associated with that particular

\footnotetext{
${ }^{13}$ It may be worth noting that a draft of the survey form that was circulated for comment (viewable at the National Archives) contained a different set of water quality measures: biochemical oxygen demand, chemical oxygen demand, suspended solids, and dissolved solids.

${ }^{14}$ See Becker and Grim (2011) for additional discussion.
} 
data storage action request. However, the position of items on the survey form, summary

statistics (e.g., means, ranges, distributions), and the published aggregate statistics allow one to deduce individual variables by comparing test tabulations to published values. For 1978 , the main challenge on this front was that the file contained data that followed one of two distinct record layouts - one for establishment-wide data and one for item-specific data.

The other main challenge, affecting both years, was that the data employed nowesoteric, non-ASCII character sets. In the case of 1973, both FIELDATA and Binary Integer were used within a record, according to the available record layout. In the case of 1978, Excess-3 (XS3) and Binary Integer were both used within a record. For technical reasons, and to speed the recovery of the maximum amount of data, all data were read, converted to an ASCII equivalent, and written to a text file on the Unisys Clearpath using two different assumptions: (i) the original data was all FIELDATA, and (ii) the original data was all XS3. However, both years also contained data fields stored as Binary Integer. The outcome for these fields were 6character strings containing a combination of the 26 capital letters, 10 numeric characters, and 28 symbols and special characters. This 6-character string is a base-64 numeric value that can be converted into the proper ASCII numeric value using a known mapping scheme (such that

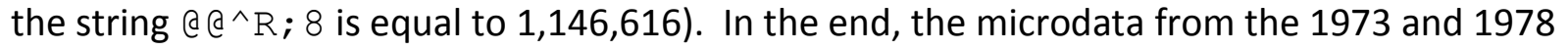
Survey of Water Use in Manufacturing are now available in modern, research-friendly formats. There are nearly 10,700 available observations in 1973 and about 9,600 in $1978 .{ }^{15,16}$

\footnotetext{
${ }^{15}$ Also recovered was data from 1973 and 1978 for about 1,690 and 1,060 establishments in mineral industries, respectively. These observations are not employed in this current study.

${ }^{16}$ Particularly in the 1978 file, additional observations appear that were not used in tabulation. For both years, I am able to identify with reasonable accuracy the cases used in tabulation. For 1973 , I am able to exactly replicate the number of sample observations reported in published tables $(10,668)$. I can also exactly replicate water intake and gross water used in virtually all 4-digit SIC industries. For 1978, I am able to come within two of the number of
} 
For 1973, after dropping observations missing key data items, suspected of having imputed data, having certain anomalies (e.g., use<intake), and/or having water intake of less than 20 million gallons (for the sake of consistency with the 1978 sample), I am left with over $92 \%$ of the original sample, about $97 \%$ of published water intake, and about $98 \%$ of published gross water used. For cases that reported not to recirculate but have use less than intake, use was set equal to intake.

For 1978, after dropping observations missing key data items, having certain anomalies (e.g., use<intake, nontabulated outliers), and/or having water intake of less than 20 million gallons, I am left with over $97 \%$ of the original sample, about $99 \%$ of published water intake, and virtually $100 \%$ of published gross water used. For cases that did not recirculate and therefore skipped Item 3 on the survey, their (missing) use was set equal to intake. For cases that reported to recirculate but have use less than intake, use derived from the sum of intake and recirculation was instead employed, if it resulted in use greater than intake, otherwise the case was dropped. For cases that reported to recirculate but have use equal to intake, use derived from the sum of intake and recirculation was instead employed, if it resulted in use greater than intake, otherwise it was assumed the establishment misreported that it recirculated.

sample observations reported in the published tables $(9,605)$, and I can exactly replicate establishment counts and water intake in all but a few 4-digit SIC industries. In 1978, replication requires restricting the sample to those with water intake greater than or equal to 20 million gallons, eliminating almost 3,000 cases. (Presumably these cases were mailed a SWUM based on their response on the CM but then proved to be out of scope.) A similar restriction is not necessary with the 1973 sample; out-of-scope cases may have already been eliminated from the file. Note that, as discussed in the previous section, in contrast to all other CMs, the primary question in 1972 was on water use (not intake). This difference appears to apply to the 1973 SWUM as well, since there are nearly 300 establishments in the tabulated sample with water intake of less than 20 million gallons, but gross water used of more than $\mathbf{2 0}$ million gallons. For the sake of consistency, I will drop these cases from my research sample. By definition, they will all be establishments that recirculated water. 
Because of the significant differences in the ways otherwise identical data items were collected, treated, and stored at the time of these surveys, I have decided to analyze the two years separately in what follows, rather than pool observations together.

\section{Results}

I begin by examining the relationship between water use and establishment characteristics, and plant size in particular. A simple regression of log gross water use intensity (i.e., gross water use divided by value added) on 4-digit SIC industry dummies and a series of establishment size indicators suggests that water use per unit of output is largest for larger establishments. ${ }^{17,18}$ At least two phenomena underlie this result.

First, as seen in the first column of Table 3a (1973) and 3b (1978), larger establishments use water for increasingly more purposes. In particular, controlling for industry, the very largest establishments (with 2500 or more employees) use water for 1.92 and 1.98 more purposes than the smallest establishments (with 1-100 employees), out of the six possible water use purposes collected on the survey. The remaining columns of Tables 3a and 3b show the coefficients from probit regressions on the probability that an establishment reported using water for a particular purpose. In all six cases, the probability that water is used for a particular purpose increases monotonically with establishment size. Naturally, the share of water used

\footnotetext{
${ }^{17}$ I do not present the results of this regression here. The coefficients from this regression are biased since the sample only contains establishments that have at least 20 million gallons of water intake. With the left part of the water use distribution missing, water use intensity will be overstated - particularly for the smallest establishments and, no doubt, attenuating as establishment size increases. Nevertheless, in spite of the bias, water use intensity is found to increase over the last three establishment size categories and the highest water use intensity is unambiguously (at least in 1973) among the very largest establishments (with 2500 or more employees). ${ }^{18}$ In the 1973 sample, the percent in each establishment size category is 19\% (1-99 employees), 26\% (100-249 employees), 21\% (250-499 employees), 18\% (500-999 employees), 11\% (1000-2499 employees), and 5\% (2500+ employees). In the 1978 sample, the percentages are $15 \%, 27 \%, 24 \%, 18 \%, 11 \%$, and 5\%, respectively.
} 
for a particular purpose may not be constant across establishment size, and indeed, in regressions not reported here, the share of total water use devoted to process, sanitation, and boiler feed each decreases as establishment size increases, while the shares increase for steam electric power generation, air conditioning, and other cooling and condensing. The other establishment characteristic included in these regressions in Tables $3 a$ and $3 b$ is an indicator that the establishment belongs to a multi-unit firm. Such establishments are found to engage in 0.21 and 0.33 more water uses, all else being equal, and they are mainly found to have a higher probability of using water for each of the purposes, with steam electric power generation and air conditioning being exceptions.

That larger establishments expand the scope of their water use would certainly explain why water use per unit of output is highest among the largest establishments. That turns out to be only part of the story. Larger establishments are also found to recirculate water more, implying greater use without necessarily greater intake. A probit regression (not reported here) indeed shows that the probability of recirculating water at all increases monotonically with establishment size. Meanwhile, Table 4a (1973) and 4b (1978) presents results of regressions explaining the natural log of the water circulation rate, which I define here as gross water use divided by water intake - or in other words, the number of times each gallon taken in is used. We saw this measure earlier in Figure 2. Results in column (1) of Table $4 a$ and $4 b$ show that the water circulation rate increases monotonically with establishment size. Here, controlling for industry, the largest establishments (with 2500 or more employees) use each gallon of water 89\% more [1978: 107\% more] than the smallest establishments (with 1-99 employees; the 
omitted category). ${ }^{19}$ Note that in the 1978 sample, there is no statistically significant difference between the omitted group (with 1-99 employees) and the next smallest establishments (with 100-249 employees).

The remaining columns of Table $4 \mathrm{a}$ and $4 \mathrm{~b}$ add additional explanatory variables to the specification. First, the SWUM collects gallons of water taken in by source, which I use to construct indicators of the establishment's primary source. These indicator variables are added to the specification in column (2), with a public water system being the omitted category. Results here suggest that when self-supplied water is the primary source - whether surface water, groundwater, or tidewater - the water circulation rate is lower than when water is from public systems. Recirculation is particularly low among establishments in which tidewater and surface water are the primary sources - groundwater less so. These are very interesting results that seems to suggest that, for some manufacturing plants, the cost of pumping (and treating) their own water is so low that (i) they choose to self-supply water in the first place, and (ii) there is less incentive to invest in recirculation. Column (3) more explicitly looks at cost - not of self-supplying per se, but for the treatment of water taken in. This variable is only available in 1973 (Table 4a). Results show that establishments with nonzero water intake treatment costs used each gallon of water $14 \%$ more than those with no such costs - an effect that increased as the per unit cost of treatment increased. Basically, the costlier the water, the more plants recirculate. Meanwhile, the addition of these variables has little qualitative impact on the results of the previously discussed variables.

\footnotetext{
${ }^{19}$ Following Halvorsen and Palmquist (1980), the marginal effect of a dummy variable when the dependent variable is measured in logs is calculated as $\exp (\alpha)-1$.
} 
Having uncovered some basic relationships between water use and recirculation, establishment characteristics, and water choices, I now explore the role certain external factors may play. One obvious possible influence is environmental regulation. That is, the more heavily regulated a facility's water pollution discharges are, the more it may recirculate water (as a substitute for discharge). Here, I construct a facility-specific measure to proxy for such regulation: the percent of an establishment's water discharge that was treated. For about 50\% [45\%] of establishments in the 1973 [1978] sample, no discharged water was treated, while all discharged water was treated in about $14 \%[15 \%]$ of cases. ${ }^{20}$ The impact of this variable's inclusion is shown in column (4) of Table $4 a$ and $4 \mathrm{~b}$. This variable is indeed found to have a statistically significant positive effect on the water circulation rate, as might be expected. Next, I add geographic variables to the specification, which will absorb additional regulatory effects, water scarcity, and other space-varying impacts. In column (5) of Table 4a and $4 \mathrm{~b}, \mathrm{I}$ add state dummies, and in column (6), I add indicators for industrial water use regions. ${ }^{21}$ The addition of these variables has some small impacts on previous coefficients but does not change the basic findings. Finally, because water scarcity can potentially vary within a state and water use region, I add county average daily precipitation to the specification. ${ }^{22}$ These results are in column (7) and show that the coefficient on precipitation is statistically zero in both years. This suggests that the aridity of a manufacturing plant's locale does not impact

\footnotetext{
${ }^{20}$ As noted earlier, "untreated" does not necessarily imply degradation in quality, and "treated" does not necessarily imply the opposite.

${ }^{21}$ The Census Bureau defined 20 such regions. As discussed in the relevant publications: "The boundaries for ... industrial water-use regions are combinations of counties without regard for State lines. These regions, which center around river basins, were developed in consultation with the Federal agencies having responsibility for water development or use and with representatives of private industry and they approximate the major drainage systems in the country."

${ }^{22}$ North America Land Data Assimilation System (NLDAS) Daily Precipitation 1979-2011, as extracted from the CDC WONDER Online Database on August 27, 2013.
} 
its water circulation rate, at least not above and beyond any effect captured by the controls for state and river basin. Indeed, when controls for state and river basin are excluded, the coefficient on precipitation is negative and statistically significant.

With this fuller set of explanatory variables, in column (7), the positive, monotonic relationship between establishment size and water circulation rates is clearly established. All else being equal, the largest establishments (with 2500 or more employees) use each gallon of water $98 \%$ (1973) and 123\% (1978) more than their smallest counterparts (with 1-99 employees). Looking specifically at 1973, the circulation rate among these largest establishments is $36 \%$ greater than the next category of plants (1000-2499 employees), which is $15 \%$ greater than the next category (500-999 employees), which is $3.2 \%$ greater than the next category (250-499 employees), which is $12 \%$ greater than the next category (100-249 employees), which is $10 \%$ greater than the smallest category. Meanwhile, establishments belonging to multi-unit firms are found to use water $13 \%$ more times (in both years).

Finally, Table 5 presents more results of regressions explaining the water circulation rate - here, adding establishment-level total factor productivity (TFP) to the specification. ${ }^{23}$ Because TFP cannot be calculated for all manufacturing establishments, there is some loss of sample when merging this in to the water use data. In particular, $11.3 \%$ and $9.0 \%$ of the sample is lost in 1973 and 1978, respectively. To see the impact of the sample loss, the regressions in column (7) of Table 4a and 4b are reestimated in columns (1) and (3) of Table 5, respectively. To make the regressions from the two years comparable, the variables associated with water

\footnotetext{
${ }^{23}$ This $\log$ TFP is a beta version constructed and employed by Foster, Grim, and Haltiwanger (2014), using longitudinal establishment-level data from the ASM and CM, together with aggregate data from other sources, including the Bureau of Economic Analysis and the Bureau of Labor Statistics.
} 
intake treatment costs are removed in 1973. The impact of TFP is shown in columns (2) and (4). Interestingly, more productive manufacturers are found to have higher water recirculation rates in 1973 but no statistically significant difference in 1978. It is not immediately clear why the effect would differ across the two years. Meanwhile, the addition of TFP does not have any large quantitative or qualitative impact on the other coefficients.

\section{Conclusion}

Water use in the U.S. manufacturing sector is fairly concentrated in relatively few industries and relatively few establishments. For many, water is extraordinarily important, with hundreds of gallons needed for just one dollar of output. While water recirculation is seen even in 1954, a sharp increase occurred in 1973 and 1978 - the two years under study here. In 1978, each gallon taken in by the manufacturing sector was used 3.4 times.

Regression results suggest that larger establishments recirculate water more. This relationship between establishment size and water circulation is found to be monotonic, and all else being equal, the largest establishments (with 2500 or more employees) used each gallon of water 98\% (1973) and 123\% (1978) more than their smallest counterparts (with 1-99 employees). Belonging to a multi-unit firm is also found to increase water recirculation, while more productive establishments are found to recirculate more, but only in 1973.

While there appears to be scale effects in water recirculation, results also suggest that water use per unit of output is largest for the largest establishments, in part because larger establishments use water for more purposes. In fact, each of the six water uses were more likely to occur as establishment size increased, with increasing shares devoted to steam electric 
power generation, air conditioning, and other cooling and condensing. What may be of particular interest is the difference between water use and recirculation-water intake per unit of output across the different establishment size groups. Unfortunately, this is difficult to address with these data, since water use and water intake are unobserved for establishments with less than 20 million gallons of water intake.

Besides increasing with establishment size, water recirculation appears dependent on various costs associated with water. In particular, the water circulation rate is found to be higher when water is purchased from a utility. Relatively low (internal) prices for self-supplied water could suppress the incentive to invest in recirculation. Recirculation is particularly low among establishments in which tidewater and surface water are the primary sources. Meanwhile, establishments with higher per-gallon water intake treatment costs also recirculate more, as might be expected. The cost associated with water discharge - due to regulation or otherwise - also increases circulation rates. The aridity of a locale is found to have little effect on circulation rates (once state and river basin is controlled for). Padowski and Jawitz (2012) have noted that there can be a disconnect between local conditions and water availability, due to the presence of rivers and manmade water infrastructure.

Future work could explore the findings of this paper further. For example, research could focus on a particular set of water-intensive industries, exploring the heterogeneity of water use and recirculation within those and the roles that particular water purposes play, as well as water sources, establishment characteristics, and locational characteristics. It may also be interesting to examine water use in conjunction with other factors of production, such as capital intensity and energy intensity (particularly fuel usage). 


\section{References}

Becker, Randy A. and Cheryl Grim. "Newly Recovered Microdata on U.S. Manufacturing Plants from the 1950s and 1960s: Some Early Glimpses," Center for Economic Studies Discussion Paper Series, 11-29, September 2011.

Bruneau, Joel F., and Steven Renzetti. "Water Use Intensities and the Composition of Production in Canada," Journal of Water Resources Planning and Management, 136(1), January 2010, 72-79.

Bruneau, Joel F., and Steven Renzetti. "A Panel Study of Water Recirculation in Manufacturing Plants," Canadian Water Resources Journal, 39(4), November 2014, 384-394.

Bruneau, Joel F., Steven Renzetti, and Michel Villeneuve. "Manufacturing Firms' Demand for Water Recirculation," Canadian Journal of Agricultural Economics, 58(4), December 2010, 515-530.

Dupont, Diane, and Steven Renzetti. "Water Use in the Canadian Food Processing Industry," Canadian Journal of Agricultural Economics, 46(1), March 1998, 83-92.

Dupont, Diane P., and Steven Renzetti. "The Role of Water in Manufacturing," Environmental and Resource Economics, 18(4), April 2001, 411-432.

Foster, Lucia, Cheryl Grim, and John Haltiwanger. "Reallocation in the Great Recession: Cleansing or Not?" NBER Working Paper No. 20427, August 2014.

Kenny, Joan F., Nancy L. Barber, Susan S. Huston, Kristin S. Linsey, John K. Lovelace, and Molly Maupin. Estimated Use of Water in the United States in 2005. U.S. Geological Survey Circular 1344, 2009.

Leone, Robert A., J. Royce Ginn, and An-Loh Lin. "Changing Water Use in Selected Manufacturing Industries," U.S. Army Engineer Institute for Water Resources Contract Report, 74-10, October 1974.

Padowski, Julie C., and James W. Jawitz. "Water Availability and Vulnerability of 225 Large Cities in the United States," Water Resources Research, 48(12), December 2012, 1-16.

Renzetti, Steven. "Estimating the Structure of Industrial Water Demands: The Case of Canadian Manufacturing," Land Economics, 68(4), November 1992, 396-404.

Renzetti, Steven. "Examining the Differences in Self- and Publicly Supplied Firms' Water Demands," Land Economics, 69(2), May 1993, 181-188. 
Solley, Wayne B., Robert R. Peirce, and Howard A. Perlman. Estimated Use of Water in the United States in 1995. U.S. Geological Survey Circular 1200, 1998.

U.S. Bureau of the Census. 1972 Census of Manufactures: Subject and Special Statistics, Volume 1. August 1976.

U.S. Bureau of the Census. 1977 Census of Manufactures: Subject Statistics, Volume 1. September 1981.

U.S. Bureau of the Census. 1982 Census of Manufactures: Water Use in Manufacturing. Subject Series, MC82-S-6, March 1986.

U.S. Bureau of the Census. History of the 1987 Economic Censuses. Washington, DC. April 1992. 
TABLE 1

Percent of Water Intake and Gross Water Use, by Purpose

\begin{tabular}{|c|c|c|c|c|}
\hline & \multicolumn{2}{|c|}{ Water intake } & \multicolumn{2}{|c|}{ Gross water use } \\
\hline & 1973 & 1978 & 1973 & 1978 \\
\hline Process & 26.3 & 28.7 & 27.1 & 33.1 \\
\hline Steam electric power generation & 18.1 & 15.8 & 8.7 & 7.8 \\
\hline Air conditioning & 1.9 & 1.6 & 4.8 & 4.2 \\
\hline Other cooling and condensing & 48.1 & 44.8 & 56.2 & 49.4 \\
\hline Sanitary services & 1.4 & 2.1 & 0.5 & 0.6 \\
\hline Boiler feed & 4.2 & 4.2 & 2.7 & 3.6 \\
\hline Other uses & $*$ & 2.7 & $*$ & 1.3 \\
\hline
\end{tabular}

* Aggregated with boiler feed in 1973. 
TABLE 2

Top Ten Water-Using Manufacturing Industries, 1978

\section{Industry (SIC code)}

Blast furnaces and steel mills (3312)

Industrial organic chemicals, n.e.c. (2869)

Petroleum refining (2911)

Paper mills, except building paper (2621)

Industrial inorganic chemicals, n.e.c. (2819)

Paperboard mills (2631)

Pulp mills (2611)

Cyclic crudes and intermediates (2865)

Primary aluminum (3334)

Phosphatic fertilizers (2874)

Alkalies and chlorine (2812)

Plastics materials and resins (2821)

Primary nonferrous metals, n.e.c. (3339)

Raw cane sugar (2061)

Cellulosic manmade fibers (2823)

Building paper and board mills (2661)

Nitrogenous fertilizers (2873)

Gum and wood chemicals (2861)

Industrial gases (2813)

Motor vehicles and car bodies (3711)

\section{Water Intake}

\begin{tabular}{lll}
\hline $\begin{array}{l}\text { Billions } \\
\text { of }\end{array}$ & $\begin{array}{l}\text { Gallons } \\
\text { per dollar } \\
\text { gallons }\end{array}$ & (Rank) \\
\hline
\end{tabular}

$\begin{array}{rrr}2,782.8 & (1) & \\ 1,909.9 & (2) & 182.3 \\ 1,149.4 & (3) & \\ 878.3 & (4) & \\ 653.8 & (5) & \\ 609.8 & (6) & 197.9 \\ 287.3 & (7) & 317.1 \\ 201.2 & (8) & \\ 200.5 & (9) & \\ 190.7 & (10) & 233.2 \\ & & \\ 175.8 & (12) & 213.7 \\ 150.7 & (13) & \\ 125.2 & (16) & 291.5 \\ 118.4 & (18) & 429.5 \\ 109.0 & (21) & 333.1 \\ 97.2 & (23) & 445.5 \\ 87.4 & (24) & \\ 39.5 & (36) & 213.4 \\ 37.3 & (37) & \\ 29.5 & (44) & \end{array}$

(2)

(3)

(1)

(8)
Gross Water Use

\begin{tabular}{lrlll}
\hline $\begin{array}{l}\text { Billions } \\
\text { of } \\
\text { gallons }\end{array}$ & (Rank) & & \multicolumn{2}{l}{$\begin{array}{l}\text { Gallons } \\
\text { per dollar } \\
\text { of output (Rank) }\end{array}$} \\
& & & & \\
$4,573.5$ & $(4)$ & & \\
$5,184.1$ & $(3)$ & & & \\
$8,151.2$ & $(1)$ & & 565.1 & $(10)$ \\
$6,377.5$ & $(2)$ & $1,179.5$ & $(1)$ \\
$1,165.7$ & $(8)$ & & & \\
$2,911.3$ & $(5)$ & 945.0 & $(3)$ \\
814.1 & $(9)$ & 898.5 & $(4)$ \\
& & & & \\
& & 658.4 &
\end{tabular}

$794.7 \quad(10)$

$1,211.7$

687.7

571.2

$\begin{array}{rr}666.8 & (7) \\ 1,008.1 & (2)\end{array}$

833.5

$1,682.7$ 
TABLE 3A

Water Use by Purpose, 1973

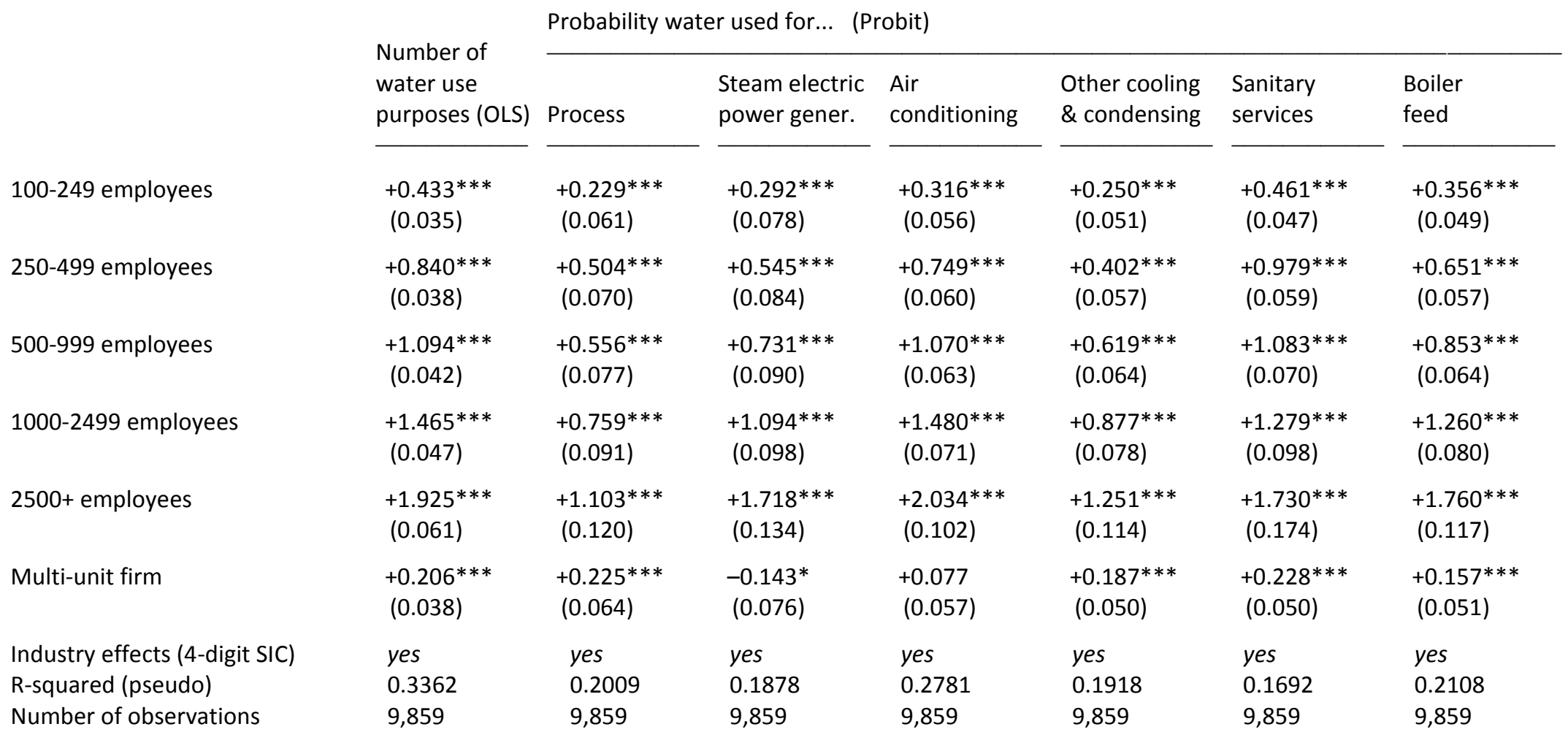

Statistical significance at the $10 \%, 5 \%$, and $1 \%$ level are indicated by single, double, and triple asterisks, respectively. Robust standard errors are in parentheses. 


\section{TABLE 3B}

\section{Water Use by Purpose, 1978}

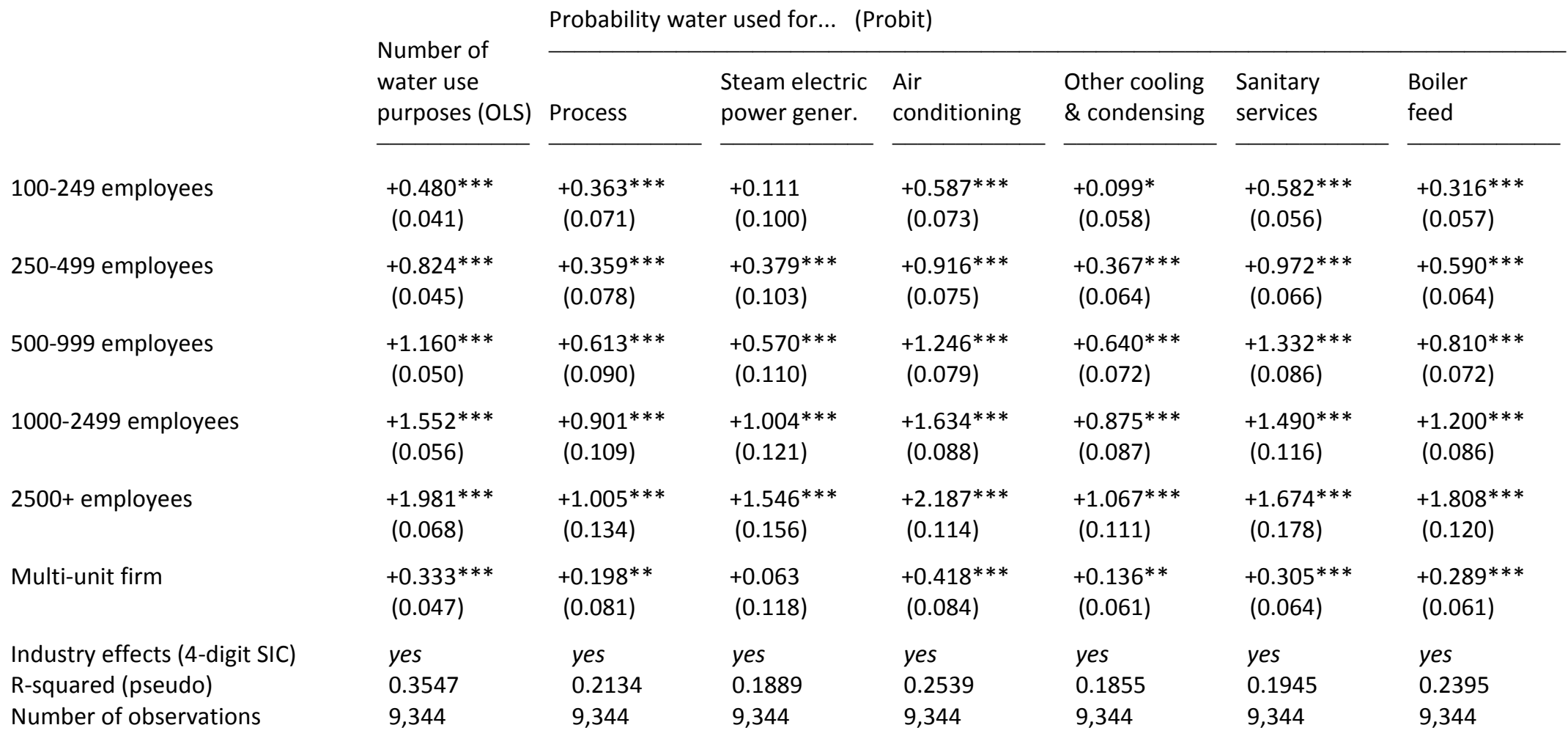

Statistical significance at the $10 \%, 5 \%$, and $1 \%$ level are indicated by single, double, and triple asterisks, respectively. Robust standard errors are in parentheses. 
TABLE 4A

Water Circulation Rate, 1973

Log (gross water use / water intake)

\begin{tabular}{|c|c|c|c|c|c|c|c|}
\hline & & & & & & & \\
\hline & (1) & $(2)$ & (3) & (4) & (5) & (6) & (7) \\
\hline 100-249 employees & $\begin{array}{l}+0.099 * * * \\
(0.029)\end{array}$ & $\begin{array}{l}+0.114^{* * *} \\
(0.028)\end{array}$ & $\begin{array}{l}+0.105^{* * *} \\
(0.028)\end{array}$ & $\begin{array}{l}+0.099 * * * \\
(0.028)\end{array}$ & $\begin{array}{l}+0.092 * * * \\
(0.028)\end{array}$ & $\begin{array}{c}+0.092 * * \\
(0.028)\end{array}$ & $\begin{array}{l}+0.092 * * * \\
(0.028)\end{array}$ \\
\hline 250-499 employees & $\begin{array}{l}+0.222^{* * *} \\
(0.032)\end{array}$ & $\begin{array}{l}+0.256^{* * *} \\
(0.032)\end{array}$ & $\begin{array}{l}+0.238^{* * *} \\
(0.032)\end{array}$ & $\begin{array}{l}+0.222^{* * *} \\
(0.032)\end{array}$ & $\begin{array}{l}+0.207 * * * \\
(0.032)\end{array}$ & $\begin{array}{l}+0.208^{* * *} \\
(0.032)\end{array}$ & $\begin{array}{l}+0.208^{* * *} \\
(0.032)\end{array}$ \\
\hline 500-999 employees & $\begin{array}{l}+0.245^{* * *} \\
(0.037)\end{array}$ & $\begin{array}{l}+0.291^{* * *} \\
(0.036)\end{array}$ & $\begin{array}{l}+0.268^{* * *} \\
(0.036)\end{array}$ & $\begin{array}{l}+0.255^{* * *} \\
(0.036)\end{array}$ & $\begin{array}{l}+0.238^{* * *} \\
(0.036)\end{array}$ & $\begin{array}{l}+0.238^{* * *} \\
(0.036)\end{array}$ & $\begin{array}{l}+0.240 * * * \\
(0.036)\end{array}$ \\
\hline 1000-2499 employees & $\begin{array}{l}+0.362^{* * *} \\
(0.044)\end{array}$ & $\begin{array}{l}+0.438^{* * *} \\
(0.044)\end{array}$ & $\begin{array}{l}+0.406 * * * \\
(0.044)\end{array}$ & $\begin{array}{l}+0.388^{* * *} \\
(0.043)\end{array}$ & $\begin{array}{l}+0.376 * * * \\
(0.043)\end{array}$ & $\begin{array}{l}+0.377^{* * *} \\
(0.043)\end{array}$ & $\begin{array}{c}+0.377^{* * *} \\
(0.043)\end{array}$ \\
\hline 2500+ employees & $\begin{array}{l}+0.635^{* * *} \\
(0.069)\end{array}$ & $\begin{array}{l}+0.755^{* * *} \\
(0.067)\end{array}$ & $\begin{array}{l}+0.713^{* * *} \\
(0.068)\end{array}$ & $\begin{array}{l}+0.673 * * * \\
(0.067)\end{array}$ & $\begin{array}{l}+0.681^{* * *} \\
(0.067)\end{array}$ & $\begin{array}{l}+0.682^{* * *} \\
(0.067)\end{array}$ & $\begin{array}{c}+0.682 * * * \\
(0.067)\end{array}$ \\
\hline Multi-unit firm & $\begin{array}{l}+0.144^{* * *} \\
(0.026)\end{array}$ & $\begin{array}{l}+0.142^{* * *} \\
(0.026)\end{array}$ & $\begin{array}{l}+0.135^{* * *} \\
(0.026)\end{array}$ & $\begin{array}{l}+0.117^{* * *} \\
(0.026)\end{array}$ & $\begin{array}{l}+0.121^{* * *} \\
(0.025)\end{array}$ & $\begin{array}{l}+0.121^{* * *} \\
(0.025)\end{array}$ & $\begin{array}{l}+0.120 * * * \\
(0.026)\end{array}$ \\
\hline Primary source: Surface & & $\begin{array}{l}-0.422^{* * *} \\
(0.034)\end{array}$ & $\begin{array}{l}-0.443 * * * \\
(0.034)\end{array}$ & $\begin{array}{l}-0.452^{* * *} \\
(0.034)\end{array}$ & $\begin{array}{l}-0.418^{* * *} \\
(0.033)\end{array}$ & $\begin{array}{l}-0.418^{* * *} \\
(0.033)\end{array}$ & $\begin{array}{l}-0.419 * * * \\
(0.033)\end{array}$ \\
\hline Primary source: Ground & & $\begin{array}{l}-0.054^{* *} \\
(0.024)\end{array}$ & $\begin{array}{l}-0.071^{* * *} \\
(0.024)\end{array}$ & $\begin{array}{l}-0.097^{* * *} \\
(0.024)\end{array}$ & $\begin{array}{l}-0.099 * * * \\
(0.024)\end{array}$ & $\begin{array}{l}-0.097^{* * *} \\
(0.024)\end{array}$ & $\begin{array}{l}-0.099 * * * \\
(0.024)\end{array}$ \\
\hline Primary source: Tidewater & & $\begin{array}{l}-0.633^{* * *} \\
(0.070)\end{array}$ & $\begin{array}{l}-0.648^{* * *} \\
(0.070)\end{array}$ & $\begin{array}{l}-0.632^{* * *} \\
(0.069)\end{array}$ & $\begin{array}{l}-0.622^{* * *} \\
(0.071)\end{array}$ & $\begin{array}{l}-0.630^{* * *} \\
(0.071)\end{array}$ & $\begin{array}{l}-0.629 * * * \\
(0.071)\end{array}$ \\
\hline $\begin{array}{l}\text { Nonzero water intake } \\
\text { treatment costs }\end{array}$ & & & $\begin{array}{l}+0.133^{* * *} \\
(0.023)\end{array}$ & $\begin{array}{l}+0.109 * * * \\
(0.023)\end{array}$ & $\begin{array}{l}+0.101^{* * *} \\
(0.023)\end{array}$ & $\begin{array}{l}+0.102^{* * *} \\
(0.023)\end{array}$ & $\begin{array}{l}+0.102 * * * \\
(0.023)\end{array}$ \\
\hline $\begin{array}{l}\text { Per unit water intake } \\
\text { treatment cost }\end{array}$ & & & $\begin{array}{l}+0.036 * * * \\
(0.008)\end{array}$ & $\begin{array}{l}+0.036^{* * *} \\
(0.008)\end{array}$ & $\begin{array}{l}+0.037^{* * *} \\
(0.008)\end{array}$ & $\begin{array}{l}+0.037^{* * *} \\
(0.008)\end{array}$ & $\begin{array}{l}+0.037 * * * \\
(0.008)\end{array}$ \\
\hline $\begin{array}{l}\text { Percent of water discharged } \\
\text { that is treated }\end{array}$ & & & & $\begin{array}{l}+0.316^{* * *} \\
(0.025)\end{array}$ & $\begin{array}{l}+0.286^{* * *} \\
(0.025)\end{array}$ & $\begin{array}{l}+0.285^{* * *} \\
(0.025)\end{array}$ & $\begin{array}{l}+0.286 * * * \\
(0.025)\end{array}$ \\
\hline $\begin{array}{l}\text { County average daily } \\
\text { precipitation }\end{array}$ & & & & & & & $\begin{array}{l}-0.014 \\
(0.023)\end{array}$ \\
\hline Industry effects (4-digit SIC) & yes & yes & yes & yes & yes & yes & yes \\
\hline State effects & no & no & no & no & yes & yes & yes \\
\hline Water use region effects & no & no & no & no & no & yes & yes \\
\hline R-squared & 0.2477 & 0.2657 & 0.2704 & 0.2833 & 0.3012 & 0.3023 & 0.3025 \\
\hline Number of observations & 9,859 & 9,859 & 9,859 & 9,859 & 9,859 & 9,859 & 9,859 \\
\hline
\end{tabular}

Statistical significance at the $10 \%, 5 \%$, and $1 \%$ level are indicated by single, double, and triple asterisks, respectively. Robust standard errors are in parentheses. 
TABLE 4B

Water Circulation Rate, 1978

Log (gross water use / water intake)

\begin{tabular}{|c|c|c|c|c|c|c|c|}
\hline & & & & & & & \\
\hline & (1) & $(2)$ & (3) & (4) & (5) & (6) & (7) \\
\hline 100-249 employees & $\begin{array}{l}+0.009 \\
(0.034)\end{array}$ & $\begin{array}{c}+0.026 \\
(0.028)\end{array}$ & & $\begin{array}{c}+0.015 \\
(0.033)\end{array}$ & $\begin{array}{c}+0.012 \\
(0.033)\end{array}$ & $\begin{array}{c}+0.013 \\
(0.033)\end{array}$ & $\begin{array}{c}+0.013 \\
(0.033)\end{array}$ \\
\hline 250-499 employees & $\begin{array}{l}+0.097^{* * *} \\
(0.037)\end{array}$ & $\begin{array}{l}+0.141^{* * *} \\
(0.037)\end{array}$ & & $\begin{array}{l}+0.122^{* * *} \\
(0.037)\end{array}$ & $\begin{array}{l}+0.112^{* * *} \\
(0.037)\end{array}$ & $\begin{array}{l}+0.113^{* * *} \\
(0.037)\end{array}$ & $\begin{array}{l}+0.113^{* * *} \\
(0.037)\end{array}$ \\
\hline 500-999 employees & $\begin{array}{l}+0.229 * * * \\
(0.043)\end{array}$ & $\begin{array}{l}+0.287^{* * *} \\
(0.042)\end{array}$ & & $\begin{array}{l}+0.261^{* * *} \\
(0.042)\end{array}$ & $\begin{array}{l}+0.247^{* * *} \\
(0.042)\end{array}$ & $\begin{array}{l}+0.248^{* * *} \\
(0.042)\end{array}$ & $\begin{array}{l}+0.248^{* * *} \\
(0.042)\end{array}$ \\
\hline 1000-2499 employees & $\begin{array}{l}+0.334^{* * *} \\
(0.052)\end{array}$ & $\begin{array}{l}+0.418^{* * *} \\
(0.052)\end{array}$ & & $\begin{array}{l}+0.388^{* * *} \\
(0.051)\end{array}$ & $\begin{array}{l}+0.371 * * * \\
(0.051)\end{array}$ & $\begin{array}{l}+0.375^{* * *} \\
(0.051)\end{array}$ & $\begin{array}{l}+0.375^{* * *} \\
(0.051)\end{array}$ \\
\hline 2500+ employees & $\begin{array}{l}+0.729 * * * \\
(0.074)\end{array}$ & $\begin{array}{l}+0.853^{* * *} \\
(0.072)\end{array}$ & & $\begin{array}{l}+0.802^{* * *} \\
(0.071)\end{array}$ & $\begin{array}{l}+0.800 * * * \\
(0.072)\end{array}$ & $\begin{array}{l}+0.803^{* * *} \\
(0.072)\end{array}$ & $\begin{array}{l}+0.803^{* * *} \\
(0.072)\end{array}$ \\
\hline Multi-unit firm & $\begin{array}{l}+0.162^{* * *} \\
(0.028)\end{array}$ & $\begin{array}{l}+0.146 * * * \\
(0.026)\end{array}$ & & $\begin{array}{l}+0.125^{* * *} \\
(0.028)\end{array}$ & $\begin{array}{l}+0.117^{* * *} \\
(0.028)\end{array}$ & $\begin{array}{l}+0.119 * * * \\
(0.028)\end{array}$ & $\begin{array}{l}+0.119 * * * \\
(0.028)\end{array}$ \\
\hline Primary source: Surface & & $\begin{array}{l}-0.427 * * * \\
(0.040)\end{array}$ & & $\begin{array}{l}-0.450 * * * \\
(0.040)\end{array}$ & $\begin{array}{l}-0.407 * * * \\
(0.040)\end{array}$ & $\begin{array}{l}-0.406^{* * *} \\
(0.040)\end{array}$ & $\begin{array}{l}-0.406^{* * *} \\
(0.040)\end{array}$ \\
\hline Primary source: Ground & & $\begin{array}{l}-0.143 * * * \\
(0.026)\end{array}$ & & $\begin{array}{l}-0.165^{* * *} \\
(0.025)\end{array}$ & $\begin{array}{l}-0.158 * * * \\
(0.026)\end{array}$ & $\begin{array}{l}-0.156^{* * *} \\
(0.026)\end{array}$ & $\begin{array}{l}-0.156^{* * *} \\
(0.026)\end{array}$ \\
\hline Primary source: Tidewater & & $\begin{array}{l}-0.761 * * * \\
(0.086)\end{array}$ & & $\begin{array}{l}-0.736 * * * \\
(0.085)\end{array}$ & $\begin{array}{l}-0.709 * * * \\
(0.087)\end{array}$ & $\begin{array}{l}-0.722^{* * *} \\
(0.088)\end{array}$ & $\begin{array}{l}-0.722 * * * \\
(0.088)\end{array}$ \\
\hline $\begin{array}{l}\text { Nonzero water intake } \\
\text { treatment costs }\end{array}$ & & & & - & - & - & - \\
\hline $\begin{array}{l}\text { Per unit water intake } \\
\text { treatment cost }\end{array}$ & & & & - & - & - & - \\
\hline $\begin{array}{l}\text { Percent of water discharged } \\
\text { that is treated }\end{array}$ & & & & $\begin{array}{l}+0.332^{* * *} \\
(0.027)\end{array}$ & $\begin{array}{l}+0.315^{* * *} \\
(0.027)\end{array}$ & $\begin{array}{l}+0.313^{* * *} \\
(0.027)\end{array}$ & $\begin{array}{l}+0.313^{* * *} \\
(0.027)\end{array}$ \\
\hline $\begin{array}{l}\text { County average daily } \\
\text { precipitation }\end{array}$ & & & & & & & $\begin{array}{c}+0.007 \\
(0.023)\end{array}$ \\
\hline Industry effects (4-digit SIC) & yes & yes & & yes & yes & yes & yes \\
\hline State effects & no & no & & no & yes & yes & yes \\
\hline Water use region effects & no & no & & no & no & yes & yes \\
\hline R-squared & 0.2429 & 0.2580 & & 0.2712 & 0.2851 & 0.2876 & 0.2876 \\
\hline Number of observations & 9,344 & 9,344 & & 9,344 & 9,344 & 9,344 & 9,344 \\
\hline
\end{tabular}

Statistical significance at the $10 \%, 5 \%$, and $1 \%$ level are indicated by single, double, and triple asterisks, respectively. Robust standard errors are in parentheses. 
TABLE 5

Water Circulation Rate, with Productivity

\begin{tabular}{|c|c|c|c|c|}
\hline & Log (gross v & r use / water & & \\
\hline & 1973 & & 1978 & \\
\hline & (1) & $(2)$ & (3) & (4) \\
\hline 100-249 employees & $\begin{array}{l}+0.096 * * * \\
(0.034)\end{array}$ & $\begin{array}{c}+0.098 * * * \\
(0.034)\end{array}$ & $\begin{array}{c}-0.029 \\
(0.040)\end{array}$ & $\begin{array}{c}-0.028 \\
(0.040)\end{array}$ \\
\hline 250-499 employees & $\begin{array}{l}+0.210 * * * \\
(0.036)\end{array}$ & $\begin{array}{l}+0.213^{* * *} \\
(0.036)\end{array}$ & $\begin{array}{c}+0.070 \\
(0.043)\end{array}$ & $\begin{array}{c}+0.071^{*} \\
(0.043)\end{array}$ \\
\hline 500-999 employees & $\begin{array}{l}+0.243^{* * *} \\
(0.039)\end{array}$ & $\begin{array}{l}+0.247^{* * *} \\
(0.039)\end{array}$ & $\begin{array}{l}+0.200^{* * *} \\
(0.047)\end{array}$ & $\begin{array}{c}+0.200 * * * \\
(0.047)\end{array}$ \\
\hline 1000-2499 employees & $\begin{array}{l}+0.382 * * * \\
(0.047)\end{array}$ & $\begin{array}{l}+0.384 * * * \\
(0.047)\end{array}$ & $\begin{array}{l}+0.331 * * * \\
(0.056)\end{array}$ & $\begin{array}{l}+0.329 * * * \\
(0.057)\end{array}$ \\
\hline $2500+$ employees & $\begin{array}{l}+0.698 * * * \\
(0.070)\end{array}$ & $\begin{array}{l}+0.702^{* * *} \\
(0.070)\end{array}$ & $\begin{array}{l}+0.754 * * * \\
(0.076)\end{array}$ & $\begin{array}{c}+0.754^{* * *} \\
(0.076)\end{array}$ \\
\hline Multi-unit firm & $\begin{array}{l}+0.131 * * * \\
(0.033)\end{array}$ & $\begin{array}{l}+0.130 * * * \\
(0.033)\end{array}$ & $\begin{array}{l}+0.105^{* * *} \\
(0.037)\end{array}$ & $\begin{array}{c}+0.104^{* * *} \\
(0.037)\end{array}$ \\
\hline Log(total factor productivity) & & $\begin{array}{l}+0.116^{* * *} \\
(0.042)\end{array}$ & & $\begin{array}{c}+0.046 \\
(0.048)\end{array}$ \\
\hline Primary source: Surface & $\begin{array}{l}-0.407^{* * *} \\
(0.036)\end{array}$ & $\begin{array}{l}-0.407^{* * *} \\
(0.036)\end{array}$ & $\begin{array}{l}-0.418^{* * *} \\
(0.042)\end{array}$ & $\begin{array}{l}-0.418 * * * \\
(0.042)\end{array}$ \\
\hline Primary source: Ground & $\begin{array}{l}-0.094^{* * *} \\
(0.027)\end{array}$ & $\begin{array}{l}-0.097^{* * *} \\
(0.027)\end{array}$ & $\begin{array}{l}-0.168^{* * *} \\
(0.028)\end{array}$ & $\begin{array}{l}-0.168^{* * *} \\
(0.028)\end{array}$ \\
\hline Primary source: Tidewater & $\begin{array}{l}-0.659 * * * \\
(0.076)\end{array}$ & $\begin{array}{l}-0.662^{* * *} \\
(0.076)\end{array}$ & $\begin{array}{l}-0.764 * * * \\
(0.091)\end{array}$ & $\begin{array}{c}-0.763 * * * \\
(0.091)\end{array}$ \\
\hline $\begin{array}{l}\text { Nonzero water intake } \\
\text { treatment costs }\end{array}$ & & & & \\
\hline $\begin{array}{l}\text { Per unit water intake } \\
\text { treatment cost }\end{array}$ & & & & \\
\hline $\begin{array}{l}\text { Percent of water discharged } \\
\text { that is treated }\end{array}$ & $\begin{array}{l}+0.295^{* * *} \\
(0.028)\end{array}$ & $\begin{array}{l}+0.295^{* * *} \\
(0.028)\end{array}$ & $\begin{array}{l}+0.317^{* * *} \\
(0.029)\end{array}$ & $\begin{array}{l}+0.317^{* * *} \\
(0.029)\end{array}$ \\
\hline $\begin{array}{l}\text { County average daily } \\
\text { precipitation }\end{array}$ & $\begin{array}{l}-0.018 \\
(0.026)\end{array}$ & $\begin{array}{l}-0.017 \\
(0.026)\end{array}$ & $\begin{array}{l}+0.002 \\
(0.025)\end{array}$ & $\begin{array}{l}+0.002 \\
(0.025)\end{array}$ \\
\hline Industry effects (4-digit SIC) & yes & yes & yes & yes \\
\hline State effects & yes & yes & yes & yes \\
\hline Water use region effects & yes & yes & yes & yes \\
\hline R-squared & 0.2981 & 0.2990 & 0.2888 & 0.2889 \\
\hline Number of observations & 8,741 & 8,741 & 8,502 & 8,502 \\
\hline
\end{tabular}

Statistical significance at the $10 \%, 5 \%$, and $1 \%$ level are indicated by single, double, and triple asterisks, respectively. Robust standard errors are in parentheses. 
FIGURE 1

Gross Water Use and Water Intake in U.S. Manufacturing, 1954-1983

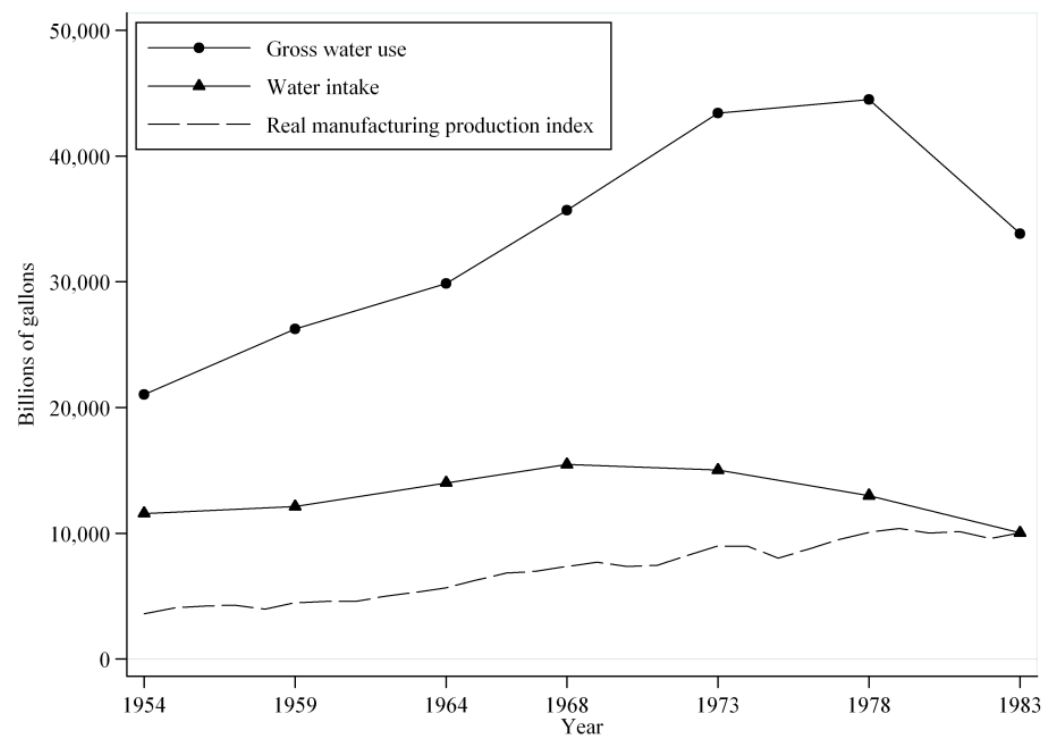

FIGURE 2

Water Recirculation in U.S. Manufacturing, 1954-1983

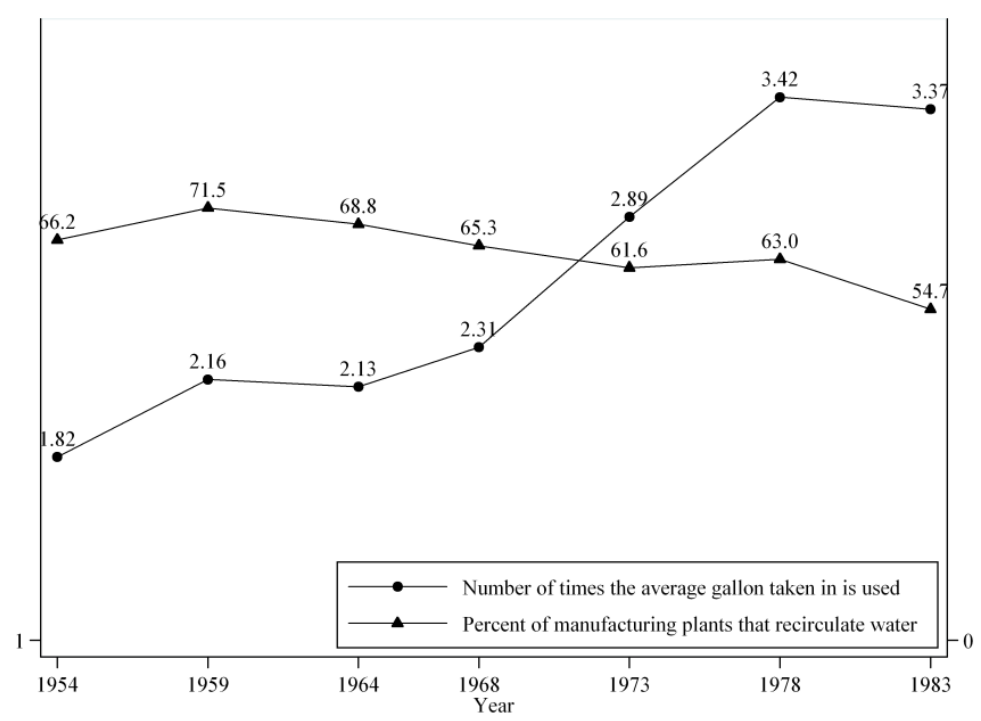


APPENDIX

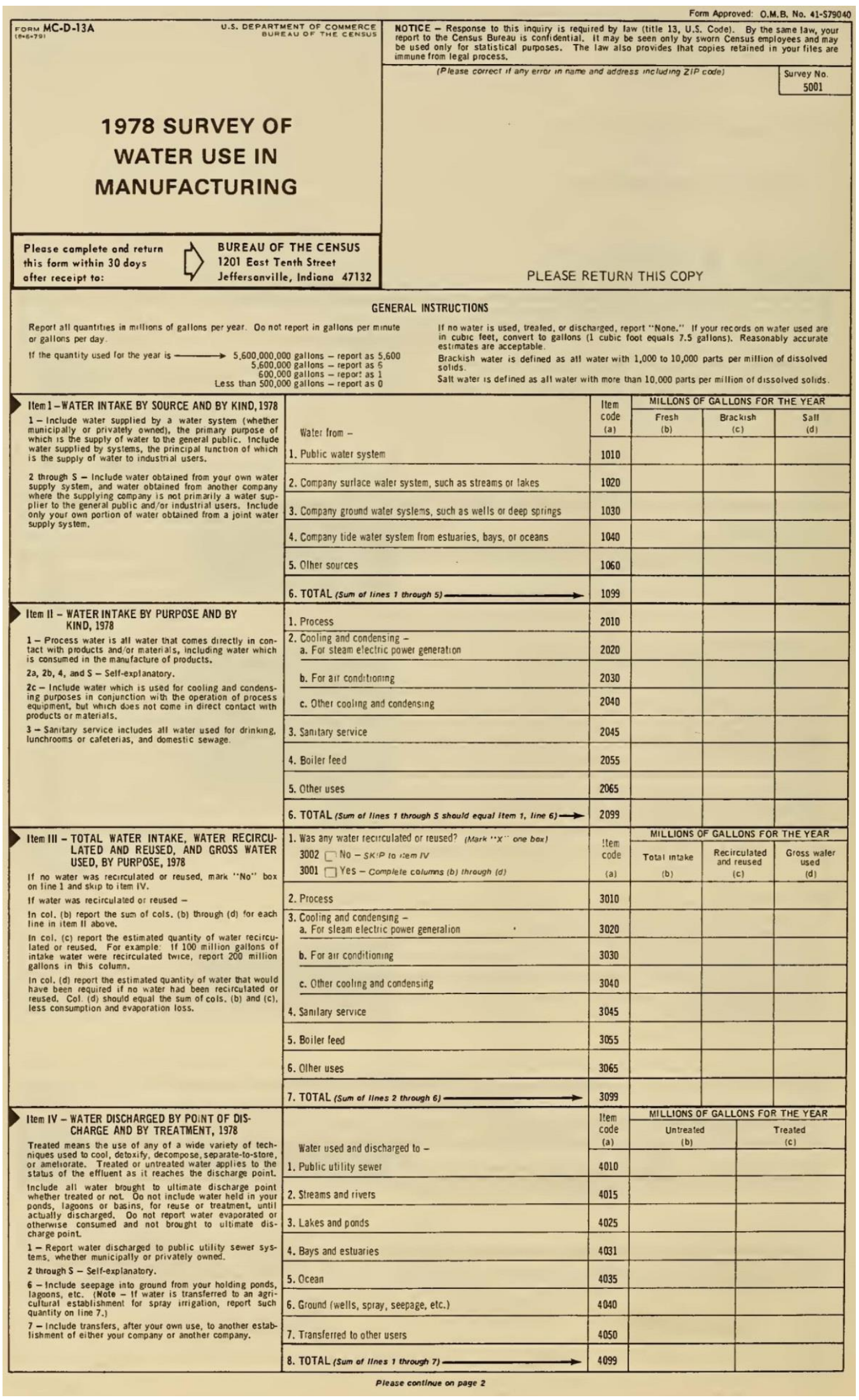




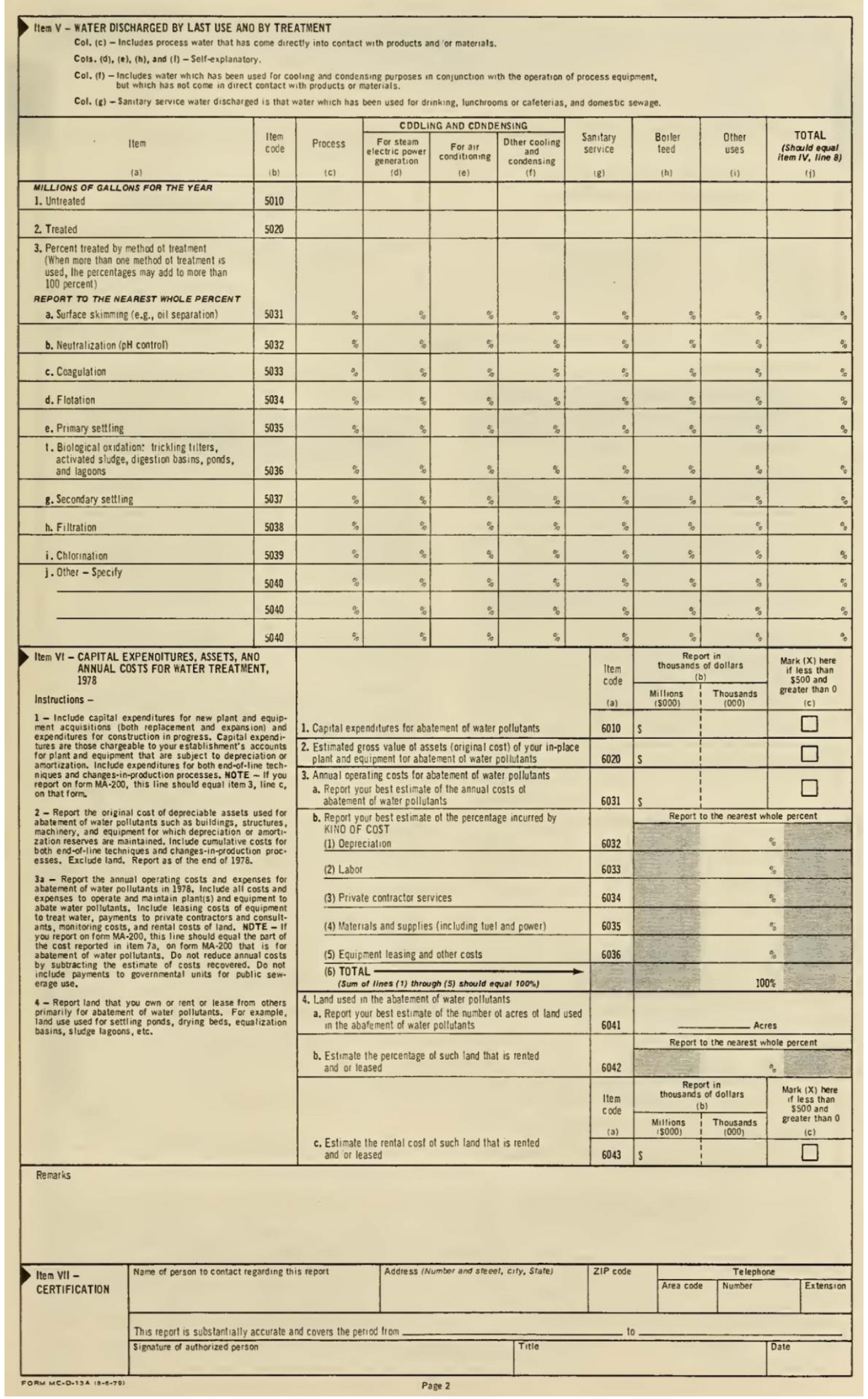

